A RISING TIDE 



\section{A RISING TIDE}

Financing Strategies for Women-Owned Firms

SUSAN COLEMAN and ALICIA M. ROBB 
Stanford University Press

Stanford, California

(C) 2012 by the Board of Trustees of the Leland Stanford Junior University. All rights reserved.

No part of this book may be reproduced or transmitted in any form or by any means, electronic or mechanical, including photocopying and recording, or in any information storage or retrieval system without the prior written permission of Stanford University Press.

Special discounts for bulk quantities of Stanford Economics and Finance are available to corporations, professional associations, and other organizations. For details and discount information, contact the special sales department of Stanford University Press.

Tel: (650) 736-1782, Fax: (650) 736-1784

Printed in the United States of America on acid-free, archival-quality paper

Library of Congress Cataloging-in-Publication Data

Coleman, Susan, 1951- author.

A rising tide : financing strategies for women-owned firms / Susan Coleman and Alicia M. Robb.

pages $\mathrm{cm}$

Includes bibliographical references and index.

ISBN 978-0-8047-7305-8 (cloth : alk. paper)—ISBN 978-0-8047-7306-5 (pbk. : alk. paper)

1. Women-owned business enterprises-United States-Finance. 2. BusinesswomenUnited States. I. Robb, Alicia M., author. II. Title.

HG4061.C64 2012

$658.15^{\prime} 2082-\mathrm{dc} 23$

2011040723

Typeset by Newgen in 10/14 Minion Pro 
This book is dedicated to my husband Bill-my most loyal reader, partner, and friend. I also dedicate this book to my mother, Jane Flint, who, like the entrepreneurs featured in this book, has been a model of courage, creativity, and grace. -Susan Coleman

This book is dedicated to my friends Diane, Nicole, Nancy, Helen, Brooke, Krista, and all the other women entrepreneurs out there who are making a positive difference in our world. And to Jerry-I'm still down five but getting closer. I'm waiting with much anticipation for your entrepreneurial venture that will change health care as we know it. -Alicia Robb 
